\title{
The Legal Concept of Liberal Reforms in Russia (Through the Example of Federalism Reform and Higher Education Reform)
}

\author{
Alexey Anisimov ${ }^{1}$ \\ ${ }^{1}$ Chair of Civil Law and Procedure, Volgograd Institute of Business, Volgograd, Russian Federation \\ Correspondence: Alexey Anisimov, Chair of Civil Law and Procedure, Volgograd Institute of Business, \\ Volgograd, Russian Federation. E-mail: anisimovap@mail.ru
}

Received: March 26, 2013

Accepted: April 17, 2013 Online Published: May 30, 2013

doi:10.5539/jpl.v6n2p168

URL: http://dx.doi.org/10.5539/jpl.v6n2p168

\begin{abstract}
The intensification of Russian citizens' political activities after December 2011 has simplified the process of political parties' registration and led to the creation of the Opposition Coordination Council. The analysis of the Council's functioning proves that it doesn't carries out the real coordination of all the opposition forces' actions. This is because the Council consists of politicians whose views differ too much. The impossibility of working out a common opposition strategy requires the development of a unified political program of opposition politicians who have similar convictions.

In these conditions the development of this program is needed for liberal politicians who mutually understand the necessity to build in Russia a democratic legal state, in which human rights would be observed. The article draws attention to some approximate structural elements of such a political program of the union of liberal parties. The author thoroughly analyzes two issues: federalism reform and education reform.

The revival of Russian federalism is supposed to include at least three lists of arrangements: renewal of budgetary federalism, i.e. the increase of regional budget revenues collected in its territory; political reorganization of regional managerial human resources including the revival of the institute of election of all governors and the determination of their performance quality characteristics regulated by the civil society. Third, this is the reform of the existing distribution of matters of competence and powers between the center and regions according to the sectoral factor. In this sense, the experience of the federative state of Canada can be used. The distribution of powers between the center and regions there is carried out not according to the sectoral factor, like in Russia, but according to the types of activity having either central or regional importance.

Education reform that is currently under way in Russia causes a series of negative consequences connected with the growth of educational process bureaucratization, reduction in financing for universities, their groundless enlargement, lack of objective criteria for evaluation of students' knowledge, and creation of the atmosphere of insecurity of the future. In this regard, the liberal concept involves the release of lecturers from paper work, election of state universities' rectors and rating system allowing taking into account the scientific and methodical contribution of each lecturer to the process of students' education, increase in financing for lecturers' salaries depending on their position in the higher educational institution's rating, and increase in financing for research activities.
\end{abstract}

Keywords: opposition, the Coordination Council, federalism, education, rating, protest, institution of higher education, efficiency

\section{Introduction}

Since December 2011 political and legal developments have taken place in the Russian Federation. A few years ago it was hard to even assume the possibility of their existence. Demonstrations of many thousand people standing for fair elections intensified the political life of the country and caused a series of repressive laws as well as tendencies among citizens toward association within the "non-system opposition". It led to the creation of the Opposition Coordination Council, i.e. a non-governmental political body created as a result of the election held on October 20-22, 2012.

In the meanwhile, the experience of the first months of the Coordination Council's activity showed that there is no unanimity within the non-parliamentary opposition. This is hardly surprising. Designed to coordinate political 
activities of all the non-parliamentary opposition forces, the Coordination Council involves 30 people which are on the "civil list". Along with this, left-wing, liberal and nationalist forces are represented by 5 persons from each party. As a result, in the Coordination Council there is always a variety of opposing opinions on any issue under discussion. The demonstrations that took place in January 2013 against the "Dima Yakovlev Law" that prohibited the adoption of Russian orphaned children by U.S. citizens revealed the signs of forthcoming split in the opposition movement. In particular, the liberal wing representatives in the Coordination Council endorsed the idea of holding such demonstrations (and participated in them) while the nationalists approved the "Dima Yakovlev Law" and ignored the demonstration on January 13, 2013.

At the present time, there are at least two political trends in the Coordination Council. The first one can be called radical. Its representatives demand to declare the election for the RF State Duma and the RF President as invalid, hold the new election and carry out serious political reforms. The second trend can be considered as moderate. Its representatives don't abuse the anti-Putin rhetoric, demand particular reforms, and want to participate in the election.

Therefore, the political forces in the Opposition Coordination Council have no uniform ideology and action plan. That is why the issue of alignment of political forces which it is composed of is nothing more than a matter of time. During several months of its existence the Coordination Council failed to work out a uniform policy, plan and mechanism of implementation of protest movement ideas. The slogan "For fair elections" is good in many ways. However, it leaves the matter in abeyance - what comes next? If such fair elections take place tomorrow, who shall participate in them? And what political, economic, social, and other ideas shall these political forces stand up for? The Coordination Council still has no answers to all these questions.

The importance of study of this problem is that, as distinguished, for example, from the U.S. bipartisan political system, in Russia (like in some other European countries) the multiparty system has been historically built. For the last ten years, when the political life in Russia had no development, many traditions have been lost. In 2012 the law that simplifies the registration of political parties was passed. Therefore, the process of political construction is under way in Russia. Various forces and ideologies including quite destructive ones participate in this process. It seems that creating the distinct concept will allow liberal forces to reunite on the basis of the same platform and take part in election. If they win, Russia will have a chance to turn into a civilized stable state that won't build communism or participate in other similar projects imposing its own ideology on other states by force of arms and provoking local armed conflicts.

The problem chosen for this study has never been raised in Russian or foreign legal literature. The Opposition Coordination Council's work is not illustrated in scientific legal literature, because it has been existing for only a few months. Its activities are not covered by the Russian mass media either. There is some information about its functioning on blogs and Internet forums, where the issues considered at the Coordination Council's meetings are being discussed. Moreover, there is no theory of the issue of problems of the modern Russian liberal opposition. It was not until 2012 that political parties standing up for liberal values appeared in Russia. Nowadays, the oldest Russian liberal party "Yabloko" has resumed its activity. Also, the social movement "Civil Platform" led by Russian billionaire Mikhail D. Prokhorov was set up. This movement has not been turned into a political party yet. Both parties have not joined the Opposition Coordination Council.

There is a vast variety of literature about liberal parties in Russia before the revolution of 1917 (Zolotukhina, 2010; Bratolyubova, 2010) as well as about their activities in the 1990s and 2000s (Golovchenko, 2008; Khanukaeva, 2008).

Regardless of this, there is no common political-legal concept of the modern liberal movement. The "Civil Initiative" is not considered to be a political party and doesn't take part in election. The "Yabloko" party has a political program that doesn't cover all the today's important economic, social, political, legal, and other issues. As one of this party's not very successful ideas from their program for the election for the State Duma of the Russian Federation (Russian Parliament) in December 2011 we can consider a proposal to provide each family in need of improvement of their living conditions with a plot of land as a private property to build a family house of up to 3,000 square meters (in central regions) and up to 6,000 square meters in Siberia and the Far East. On the whole, they planned to provide citizens with 5.6 million hectares of land. To prevent land speculation, they proposed to indicate in the corresponding agreements with citizens that a plot of land must be developed during a fixed period of time, for instance, 3 years. Along with this, the state was obliged to make commitments to provide these houses with access to communal infrastructure. All the families involved in this process were supposed to get a special certificate. Also, they proposed a series of measures to render financial assistance to these families (Strategy "Land-Houses-Roads" by the "Yabloko" party, 2011). 
In the meanwhile, it is impossible to put this proposal into practice as a matter of principle. The point is that the whole land fund of Russia totals 1,709.8 million hectares. As part of it, lands of populated areas cover 19.5 million hectares (State report, 2010). Only lands of populated areas can be used for building houses. Consequently, their total area will increase by almost $25 \%$. In fact, there aren't so many spare and unoccupied lands in Russia. The only way to implement this program is to turn agricultural lands into lands of populated areas (cottage settlements). However, such an idea will bring glory to no party. Besides, as a general rule, low-income families do not have financial resources for this building (even taking account of the promised state support). Therefore, most families won't be able to take advantage of this program. Taking into consideration the existing Russian reality, mass free provision of such plots of land will cause the increase in corruption and there resale to more well-off citizens for real sums of money, that is the same speculation the rest of Russian political parties propose to fight against.

However, it doesn't imply that liberal parties are not able to propose reasonable reforms. The program of the "Yabloko" party in the sphere of corruption fighting, promoting the building sector, road building, their environmental projects, and family policy don't provoke any principal objections.

It appears that, at the present time, politically active Russian citizens have an opportunity to create new liberal political parties, which will be able to join together in the course of time, form an electoral bloc, and take part in election for bodies of legislative and executive power. The hypothesis of the study is that it is quite possible to outline the main structural elements of this common political program. It includes the following elements: reform of court system; military reform (including the creation of professional army); reform of federative relations; reform of local self-government (first of all, enhancing its financial independence); economic reform (including the transition to innovation-driven economy and the refusal of priority of raw material industry development); education reform; healthcare reform; environmental reform; social welfare reform, etc.

It is impossible to analyze all the directions in one article. That is why the author has chosen the problems of federalism and higher education from this list and is planning to raise the other aspects later in this journal. As for the problems of federalism and higher education reforms in Russia, they are currently under serious discussion. Representatives of both the governmental bodies and the opposition participate in it. This allows representing the position of liberal political forces on this issue giving grounds for the principle objections to the government's plans. The corresponding arguments can be used as a strategy and tactics by the future union of liberal parties in the course of election campaigns. This aspect will represent the theoretical and practical importance of the author's current study.

The problems of federalism and higher education reform themselves are quite broadly discussed in Russian and foreign political and legal science. Besides, there are studies of historical problems (Khovanskikh, 2006) as well as modern general-theoretical problems of Russian federalism (Ponomarev, 2005; Chernov, 2006, Kim, 2009). The works on certain practical aspects of necessity of Russian federalism reforms should be particularly mentioned. Such quite substantial works are devoted to federalism in the context of land relations (Melikhov, 2007; Stepanenko, 2012), labor relations (Shvedov, 2006), budgetary federalism (Novikova, 2006) and tax federalism (Lazarev, 2009), peculiarities of organization of law enforcement agencies' activity in the federative state (Medvedeva, 2002), economic aspects of federalism (Khvoshchin, 2007), etc.

The theory of education is also represented by a series of interesting and substantial works. The list of issues considered in them can vary from the analysis of constitutional rights in the sphere of education on the whole (Tretyak, 2011), administrative-legal organization of the education system (Barabanova, 2004) up to the problems in the sphere of education on particular specialties and areas (Gorbatova, 2007).

In the meantime, these proposals are not adapted to the unified concept of the bloc of liberal parties. And sometimes they cannot be involved in the context of the present-day political life of Russia. It requires the analysis of the stated proposals, their comprehension and addition depending on the realities of political and legal life of Russia.

\section{Research Methods}

In the article the author applies the system analysis method, comparative-legal method, historical analysis method, and statistical method.

\section{The Liberal Concept of Federalism Reform in Russia}

\subsection{The Real Content of Federative Relations in Russia}

The presidential concept of Russian federalism has never had a form of a report or an article. The substantial part of this concept, that has been implemented by Vladimir V. Putin since his coming to power in 2000 and that he continues improving up to the present time, can be represented in the following way: 
- for the purpose of preventing regional separatism, election in provinces must have a formal character while governors must be appointed by the president. Professional qualities of such a governor and the extent of the population's confidence in him do not matter. The only important thing is that this governor must be loyal to the President of Russia.

- the RF constituent entities must have a minimum quantity of revenues to the budget from various types of activity carried out in their territory. To perform their functions, they are provided with grants and subventions from the federal budget. As a result, regional leaders are not independent and have to play a role of suppliants in the Center.

- the RF constituent entities are not allowed to adopt a full-scale regional legislation, because the most important areas of legislation have been withdrawn from the sphere of their competence. As for the rest of issues, their statutory regulations cannot be in contradiction with numerous federal laws encroaching on their rights. The last aspect of the problem of federative relations will be considered in detail.

\subsection{The Distribution of Matters of Competence between the Federation and Its Constituent Entities}

The draftspersons of the Constitution of Russia of 1993 have included in it Articles 71 and 72 devoted to the matters of exclusive competence of the Russian Federation as well as of joint competence of the Russian Federation and its constituent entities. As a result, for instance, criminal and civil legislation fell within the matters of exclusive competence of the Russian Federation, while land and environmental legislation turned out to be within the joint competence of the Russian Federation and its constituent entities. Including a particular area in Article 71 of the Constitution implies an absolute impossibility for the RF constituent entities to pass laws on any legal issues. Within the framework of joint competence the RF constituent entities are only allowed to pass their own laws as prescribed by federal laws related to the matters of joint competence. As a result of such an approach, it appears that the RF constituent entity is not allowed to pass its own regulations on any minor civil law issue, while within the framework of joint competence (for instance, in the sphere of land relations) the laws passed by the RF constituent entities can only be related to insignificant third-rate issues. Otherwise, they are supposed to contradict federal laws and will be revoked.

Such a centralization of public relations management caused the lack of federalism in Russia in the ordinary sense. The laws of the RF constituent entities are less informative. There are very few of them, and they regulate practically nothing. As a rule, local peculiarities aren't taken into account. However, there are quite a few examples of such local peculiarities. Thus, in mountainous areas of Russia (for instance, in the Republic of Dagestan) mountain pastures and other plots of land that could be used in agriculture had historically been in public use. The Constitution of Russia and the RF Land Code declared private ownership of land. As a result, certain well-off citizens began to legally purchase these plots of land. More often they used corrupt practices. Consequently, inhabitants of auls (mountain villages) turned out to have no land to tend cattle and grow agricultural products. The tense political situation that currently exists in many Caucasian Republics was caused not only by external factors (impact of wahhabism) but mainly by internal ones connected with the disregard for the population's way of life and traditions. In the meanwhile, the constituent entity of the Federation is not allowed to pass a law to restrict the circulation of such lands, because it will run counter to the Constitution of Russia and the RF Land Code.

It seems that, when including a particular area of legislation in the number of matters of exclusive or joint competence of the Russian Federation and its constituent entities, the authors of the Constitution took as a basis the level of law comprehension that existed in the USSR legal science in the 1970s. The core of this law comprehension is that there is a unified complete list of areas of law and legislation, provided that these areas don't interact in any way, and the scopes of their application don't touch. In other words, in their opinion, for example, there is kind of the Berlin Wall with no cracks between land legislation and civil legislation. It was probably a matter of fact in the time of the USSR. There were very few laws and other legal regulations in the USSR. Moreover, the ones that existed could hardly regulate anything in fact. The economy was highly centralized. The complicated economic relations were regulated by the party decisions and ministerial circular notes. However, at the beginning of 1990s the role of law in the regulation of economic, political, social, and other processes had significantly increased, that led to the dramatic growth in number of laws regulating the variety of public relations.

At the same time, purely practical goals and tasks facing legislative bodies have stipulated the adoption of laws which don't belong to any particular area of legislation (civil, land, environmental, etc.). Such laws included legal standards which belonged to different legislation areas. Here is a vivid example. In Russia there is the Federal Law "On the agricultural land transactions" passed on July 24, 2002. It regulates relations in the sphere of purchase and sale, lease, trust management, apportionment of participatory share of join property in regard to agricultural lands, 
i.e. land plots as property objects. The law includes civil law regulations as well as land law regulations. Simply said, this is an omnibus law that doesn't belong to any particular area. But if the law consists of both civil and land law regulations, is it possible to pass laws in the RF constituent entities in its furtherance? In other words, how can you determine whether the adoption of such omnibus laws falls within the federal competence or joint competence of the Russian Federation and its constituent entities?

The Russian science of constitutional law doesn't answer these questions and even avoids raising them. This is because the inaccurate understanding of federalism included in the Constitution doesn't allow getting the answers. In this sense, the more reasonable concept has been developed in countries of common law (Great Britain, the USA, Canada). There is no official division of the system of law into areas having strict boundaries in these states.

\subsection{Possible Directions of Russian Federalism Reform}

Within the context of the suggested politico-legal platform for combining liberal forces, the development of a new model of federalism is required. Its main idea should be that the Russian Federation passes framework laws on all issues of state importance in which there must be a clear list of principles and procedures to be implemented in the corresponding spheres of public relations. For instance, in regard to land relations these principles should relate to procedures (in what cases to hold a tender), restrictions (what categories of lands have been withdrawn from civil circulation), fundamentals of separation of powers between the Russian Federation, its constituent entities and local government bodies. On the basis of these principles, the RF constituent entities pass their own laws taking account of local specifics. The development of this model of federalism will be a novelty only for Russia. In most other federative states in the world such a model has been successfully functioning. The Civil Code of the Canadian province of Quebec is a model to emulate and an object of study in many countries throughout the world.

To revive federalism, it is necessary to return to the real election of governors by the population of the RF constituent entities and develop a mechanism of recall of a governor by voters as well as his accountability to the electorate. In its turn, it requires the development of formal and transparent criteria to evaluate the quality of governors' work. First of all, they should relate to their socio-economic policy (number of social objects that were built up or closed down, amount of aid from the RF constituent entity's budget to those categories of citizens who have allowances and benefits according to the regional legislation, etc.).

The special attention should be paid to budgetary federalism reform. It seems necessary to link the powers of the local self-government body and the RF constituent entity with the structure of their revenues and expenditures. It is important to restore special-purpose budgetary funds, which would be formed due to special taxes and charges and spent to promote some certain types of activity. In the 1990s there was a plenty of such special-purpose budgetary funds. However, later they were acknowledged to be unreasonable. Several years ago the road fund was restored. It accumulates various payments for the use of roads. Then its financial resources are used to build and repair roads. There was also the environmental fund that accumulated fines, payments for emissions affecting the environment, and other charges. The financial resources of this special-purpose budgetary fund were spent for the environmental protection only. Such a model is believed to be more reasonable than the current one, when these incomings dissolve in the total estimate of budgetary revenues while expenditures for the environmental protection are determined residually.

\section{Problems of Higher Education Reform}

The Federal Law "On education" signed by the RF President on December 29, 2012 solves none of the problems actually facing the Russian education system. It only aggravates the existing negative trends that must be overcome at any cost.

Let's determine at least some of these trends and ways of overcoming the crisis:

1) one of the main problems of the Russian education is an excessive bureaucratization of the education process. This trend can be evident at the "macrolevel" as related to non-transparent and thus potentially corruptive appointment of higher educational institutions' leaders regardless of their qualification, experience and the personnel's attitudes, licensing, national accreditation, control (supervision) over institutions of higher education as well as at the "microlevel" as related to redundant requirements for the development of schedules, reports, working programs, teaching materials, etc.

Consequently, in case when lecturers in most of Russian higher educational institutions have 900 hours of teaching load per year, they have to give all their time that is free from teaching not to having a rest or improving their professional skills but to filling out numerous and constantly changing tables, schedules, reports, etc. This routine work is absolutely pointless, as the quality of education doesn't depend on the amount of paper. 
However, instead of abolishing redundant and unnecessary bureaucratic procedures, establishing the number of minimum requirements for the quantity of premises, the content of libraries, a series of other formal requirements as well as the methods of calculating the minimum rating of higher educational institutions that is enough to fulfill pedagogical functions, the law savors the quantity of education programs, maintenance of their registers, conduct of examinations, strengthening of control, supervision, monitoring, obligatory credits in education programs, and other senseless bureaucracy. Moreover, most of Moscow institutions of higher education don't possess a right to participate in discussion of those programs they are supposed to implement. The authors of the law honestly believe that officials of the Ministry of Education know much better than lecturers how to teach students.

2) at the present time, there is no system of criteria for evaluating the quality of work of higher educational institutions. The attempts of the RF Ministry of Education to conduct the monitoring of performance efficiency among Russian institutions of higher education have shocked the pedagogical community by their incompetence and unreasonableness. In particular, they have suggested that the efficiency of higher educational institutions should be evaluated according to four directions:

a) educational activities (matriculated students' grade point average of the uniform state exam, number of graduates who got the government and president's scholarships, percentage of graduates who were employed during one year after graduation);

b) research activities. Among the other criteria they distinguished the percentage of expenses for research and development of the total income and expenditure of the higher educational institution;

c) international cooperation. In the total number of students they took into account the percentage of foreign students apart from citizens of the Commonwealth of Independent States, Baltic States, Georgia, Abkhazia, and South Ossetia as well as the quantity of students who were accepted into the postgraduate programs and had training courses in foreign institutions of higher education;

d) financial and economic activities. Among the other criteria they took account of the higher educational institution's income from all the sources calculated per one employee and the correlation between the average monthly salary of research and teaching personnel and the average salary according to the economic indicators in the region (Portal of the Federal state educational standards, 2013).

These criteria are far removed from objectivity for the following reasons:

a) how is it possible to draw a conclusion about the quality of education according to the criterion of the foreign students' presence in the higher educational institution, provided that they don't even include those from the Commonwealth of Independent States? It was probably a good idea for Moscow, but what about foreign students in provincial institutions of higher education? It could be possible to train them in medicine, physics, mathematics and so on (at least as a potentiality). But it's really hard to imagine that any foreign student will be eager to study the Russian law or history and come to Ryazan or Volgograd.

b) one of the "efficiency" criteria was the number of students accepted into the postgraduate programs (postgraduate students) who had training courses in foreign institutions of higher education. For Moscow State University or some other Moscow institution there is at least a possibility to send their postgraduate students to the USA or any other developed country for training at the expense of the institution. Speaking about free training courses at the expense of the host institution, such a possibility is incommensurable in Moscow and regional institutions of higher education. It seems that the Ministry of Education has no real vision of the situation in Russian education.

c) students in Moscow and Saint Petersburg will definitely have the highest grade point average of the uniform state exam, as these cities accumulate the most talented students from all over the country. After graduation most of them stay there (if they have such a possibility). However, it doesn't mean that all the other institutions of higher education where the grade point average is low are of poor quality. For instance, Volgograd Social Pedagogical University was acknowledged to be inefficient, because it accepted students from non-urban areas, provided that they return upon graduation. Such applicants did have the low grade point average of the uniform state exam. But is there any other way to get teachers for rural schools?

In the meanwhile, it would be possible to provide much more objective evaluation of the institution's work on the basis of the rating system. Its main idea is that it takes account of the rating of each lecturer, chair, department, and institution based on simple, public and verifiable criteria. They can include publications in peer-reviewed journals, science citation index, availability of teaching materials recommended by the Ministry of Education, patents for invention, etc. In particular, it is possible to take into consideration the authors' teaching methods which can be easily verified by attending demonstration lectures (or watching them on the institution's website), calculating the 
number of obtained grants and the quantity of students who participated in academic competitions and gained prizes, etc. Such a rating system will allow prompt determination of who is who, i.e. the institution that really works hard as well as the one that only throws dust in the eyes. Consequently, the lecturer's salary must directly depend on its position in the rating (instead of the system of equal salaries that exists since the Soviet time and doesn't care if the lecturer works hard or just "dozes off" during the lectures). At the same time, the position of the department and institution in the rating must be a decisive factor when contemplating the possibility of setting up Master's degree programs and dissertation councils. Moreover, their establishment should be of a notifying character and not of a permissive one as it is now, i.e. the rating position by itself gives grounds for the institution's leader to make a corresponding decision and notify the Ministry afterwards.

The very fact that there are still no even mere attempts to work out such ratings can be easily explained. Their creation will instantly destroy the bloated undeserved fame of certain Moscow, Saint Petersburg and many other higher educational institutions, which are absolutely undistinguished except for the preferences of the nation's leadership. Along with this, the lack of such a system of evaluating the institution's performance efficiency doesn't allow making reasonable management decisions. In its turn, it makes the system of education management corruptive and inefficient.

3) it has already been said much about the inefficiency of the uniform state exam system that school leavers have to pass. Its results (points) are considered as grounds for being accepted into higher educational institutions. The authors of this system have implicitly acknowledged that it is senseless by permitting some Moscow institutions which they have personal preferences for to conduct entrance examinations. The drawback of this system is that it is much more difficult to carry out anti-corruption control over several hundred thousand schools than over several hundred state institutions of higher education. As a result, there is often such a situation when an applicant coming from the Caucasus Mountains has maximum points of the uniform state exam and at the same time hardly speaks Russian. To combat corruption in the higher school, it will be enough to install web cameras (left after the presidential elections) in the classrooms where entrance examinations are held. Any representative of the civil society should be allowed to watch them with the further possibility to appeal their results in court. The lecturers being on the top of the rating list and affiliated with a certain consulting structure under the Governor could be an arbitrator while evaluating the quality of entrance examination answers. The court could admit their report along with other evidence in the case.

4) the law doesn't solve the problems of providing the quality of graduates' knowledge. Article 59 of the Law on education related to the final certifying examination, apart from a series of reference regulations, focuses on some minor technical issues of its conduct. In the meanwhile, the quality of knowledge could be provided by means of the testing system used in the end of each academic year on the issues recommended by the academic community with participation of the employer's regional representatives. Standard questions and results of this testing in all the disciplines studied in the institution should be posted on the institution's website and taken into account in the general rating of the institution. The conduct of such tests will be much more effective than the "accreditation examinations" prescribed by law. The experts for them are usually assigned by non-transparent methods regardless of their real deserts and competence.

5) one of the most popular topics under discussion in the sphere of the education reform is a continuing enlargement of Russian federal institutions of higher education. This process depends on the obscure bureaucratic logic without regard to the institution's personnel's opinion as well as any objective, transparent and clear criteria. The procedure of acknowledging inefficient with further amalgamation of some leading Russian institutions of higher education has already provoked protest and disobedience actions on the part of personnel and students of Russian State Trade and Economic University (RSTEU). They believed that the reason why the university can be acknowledged inefficient is that the officials wanted to deprive it of its building in the center of the city where the cost per square meter is too high. The very methods of this amalgamation of institutions can often be compared to the standard forcible takeover. In the meantime, the establishment of the committee consisting of representatives of the academic community, civil society and government agencies with the public discussion of its goals and tasks would be much more civilized.

6) today one of the key problems within the education system is the problem of salary of the institution's lecturers. The salary of professors in provincial universities is $\$ 750$ per month, associate professors $-\$ 500$ per month, young lecturers/assistants - \$270-280 per month. Of course, it must be either an enthusiast or the one who failed to get any other job who will work for such a salary. Besides, as it has already been mentioned above, the salary rate doesn't depend on the work results. Such a situation, on the one hand, leads to the absolute indifference of the lecturer towards the creative advancement. On the other hand, just in order to survive the lecturer has to take small bribes from students. Article 99 of the Law on education offers to fix salary rates for lecturers according to the 
average salary in the region. It is not yet clear how to calculate this "average temperature" as well as whether the lecturers' financial situation will really improve. At any rate, it won't be enough. All those who didn't manage to find another job can't have free access to the research and education corporation. To enhance the corporation prestige, the whole system of measures to evaluate the quality of the applicant's knowledge and skills is required. It should also check the applicant's practical experience, inclination for research, awareness of teaching methods, and psychological preparedness for working with students. There is no sense to discuss the quality of knowledge until all these measures are taken.

7) even taking account of those enthusiasts who keep trying to advance Russian science, the problem still remains. In Russian scientific publications and mass media the attention is drawn to the fact that material resources of Russian scientific institutions (even in Moscow) remain unchanged since the 1980s. In Russian provinces it is still possible to find the equipment that was used in the 1950-60s. Since then, a qualitative breakthrough has been made in many fields of science. That is why to use such an outmoded equipment in research is "like to solve the problems of quantum chemistry using an arithmometer" (Vakhitov, 2013). In many ways, this fact makes Russian science inefficient.

\section{Conclusions}

The conducted study allows the following conclusions:

- as a result of the increasing number of Russian political parties expressing the interests of various groups of the population and based on different systems of values, the issue of creating the unions of such large and small parties is supposed to be raised in 1 or 2 years. In this regard, liberal parties will inevitably participate in this process. It seems important to start working out the unified political platform of this union on some key political, economic, and other issues;

- the Opposition Coordination Council founded by representatives of too different political forces failed to unite the Russian non-parliamentary opposition. Representatives of the two largest liberal parties and movements didn't join it. Taking into consideration that both sides do not want to start a dialogue, a new opposition coordination structure will probably appear in Russia soon;

- the state structure of Russia being federal according to the Constitution each year acquires more and more signs of a unitary state. It is obvious that powers of regional authorities have been restricted while their dependence on central government agencies has increased. In the meantime, the Russian regions historically always had different levels of economic, cultural, social, and other types of development. It is unreal to take into account these specific features from Moscow. The existing system of public administration, in which the regions' powers are significantly restricted, doesn't allow the effective state administration;

- the revival of Russian federalism is supposed to include at least three lists of arrangements: renewal of budgetary federalism, i.e. the increase of regional budget revenues collected in its territory; political reorganization of regional managerial human resources including the revival of the institute of election of all governors and the determination of their performance quality characteristics, which would be transparent and accountable to the civil society; abolition of the system of distribution of matters of competence and powers between the center and regions according to the sectoral factor. In this sense, the experience of the federative state of Canada can be used. The distribution of powers between the center and regions there is carried out not according to the sectoral factor, like in Russia, but according to the types of activity having either central or regional importance. That is why there is the Civil Code of the province of Quebec in Canada, while there can't be the Civil Code of the Volgograd region in Russia. Though in both countries there is an objective necessity to regulate a certain part of property relations at the regional level. This fact must be taken into account in the proposed program of the union of liberal parties;

- education reform that is currently under way in Russia causes a series of negative consequences connected with the growth of educational process bureaucratization, reduction in financing for universities, their groundless enlargement, lack of objective criteria for evaluation of students' knowledge, and creation of the atmosphere of insecurity of the future, vanity and abuse of power. In this regard, the liberal concept involves measures to reduce the bureaucratization in higher educational institutions, create the institute of election of state universities' rectors and the rating system allowing taking into account the scientific and methodical contribution of each lecturer to the process of students' education, increase financing for lecturers' salaries depending on their position in the higher educational institution's rating, and increase financing for research activities.

The mentioned recommendations can be included in the political program of the union of liberal parties. In the author's opinion, it will come into existence in the nearest future. 


\section{References}

Barabanova, S. V. (2004). State regulation of higher education in the Russian Federation: administrative-legal issues. Kazan, 340 p.

Bratolyubova, M. V. (2010). Views of the Don liberal activists at the beginning of the $20^{\text {th }}$ century concerning the problems of political reorganization of society. Vestnik of Volgograd State University (Series 4: History, Regional studies, International relations), (1), 27-34.

Chernov, S. N. (2006). Legal problems of theory and practice of the constitutional regulation of relations between the Russian Federation and its constituent entities. Candidate's thesis in law, 4-23. Petrozavodsk.

Golovchenko, A, V. (2008). Liberal parties in the political spectrum of modern Russia (through the example of the political parties "Union of Right Forces" (SPS) and "Yabloko"). Synopsis of a candidate's thesis in political science, 3-36. Saratov.

Gorbatova, M. K. (2007). Higher legal education in modern Russia: theoretical-legal aspects of development. Synopsis of a candidate's thesis in political science. Nizhny Novgorod, 3-24.

Khanukaeva, I. R. (2008). Liberal parties in modern Russia: formation, development, and prospects (through the example of the "Union of Right Forces" and the "Yabloko"). Synopsis of a candidate's thesis in political science, 5-19. Moscow.

Khovanskikh, A. Y. (2006). Principle of federalism in the Russian law: historical- and theoretical-legal aspect (1917-1991). Candidate's thesis in law, 4-56. Samara.

Khvoshchin, A. A. (2007). Constitutional-legal aspects of economic federalism in the Russian Federation. Synopsis of a candidate's thesis in law, 4-22. Tyumen.

Kim, Y. V. (2009). Federative statehood: essence, genesis, and problems of development (theoretical-methodological fundamentals). Candidate's thesis in law, 6-16. Tyumen.

Lazarev, V. I. (2009). About tax federalism. State Power and Local Self-Government, (9), 23-24.

Medvedeva, E. Y. (2002). Principle of federalism and organization of the Russian militia's activities. Synopsis of a candidate's thesis in law, 4-9. Moscow.

Melikhov, A. I. (2007). Private property right to plots of land: constitutional-legal aspect. Synopsis of a candidate's thesis in law, 4-21. Volgograd.

Novikova N. I. (2006). Budgetary federalism: problems of theory and practice. Candidate's thesis in law, 52-68. Moscow.

Ponomarev, V. V. (2005). Legal collisions in federative relations in the Russian Federation: constitutional-legal mechanism of overcoming. Candidate's thesis in law, 7-70. Rostov-on-Don.

Portal of the Federal state educational standards of higher professional education. (2013). Retrieved January 20, 2013, from http://fgosvpo.ru/index.php?id=174\&menu_id=21\&menu_type=4\&parent $=0$

Shvedov, A. L. (2006). Delimitation of powers between federal governmental authorities and governmental authorities of the Russian Federation constituent entities in the sphere of relations regulated by labor law. Candidate's thesis in law, 13-126. Ekaterinburg.

State (national) report about the state and use of lands in the Russian Federation in 2009. (2010). Moscow.

Stepanenko, R. A. (2012). Theoretical-legal aspects of the delimitation of matters of competence between the Russian Federation and its constituent entities in the sphere of land legislation. Candidate's thesis in law, 12-153. Stavropol.

Strategy "Land-Houses-Roads" of the "Yabloko" party. (2011). 22-29. Moscow-Saint Petersburg.

Tretyak N. V. (2011). Constitutional right to education in the Russian Federation. Synopsis of a candidate's thesis in law, 3-23. Moscow.

Vakhitov, R. (2013, April 11). Liquidator. Otechestvennye Zapiski, 6.

Zolotukhina, E. K. (2010). Human rights in policy papers of Russian liberal parties at the beginning of the $20^{\text {th }}$ century. History of State and Law, (18), 19-22. 


\section{Copyrights}

Copyright for this article is retained by the author(s), with first publication rights granted to the journal.

This is an open-access article distributed under the terms and conditions of the Creative Commons Attribution license (http://creativecommons.org/licenses/by/3.0/). 